\section{First Impressions and Rethinking Restroom Questions}

\author{
Lorraine J. Pellack, \\ Guest Columnist
}

Correspondence for Reference \& User Services Quarterly should be addressed to Editor Diane Zabel, Schreyer Business Library, The Pennsylvania State University, 309 Paterno Library, University Park, PA 16802; e-mail:dxz2@psu.edu.

Lorraine J. Pellack is Head, Science and Technology Department, Parks Library, lowa State University, Ames, lowa.
In her inspirational article in the Winter 2008 issue of RUSQ ("A Personal Choice: Reference Service Excellence") Marie Radford reminds us that reference service excellence begins with the initial patron interaction, whether it is face-to-face or virtual. In this guest editorial, Lorraine J. Pellack reinforces the importance of first impressions formed by patrons. Coincidentally, Pellack's point mirrors the message contained in Susan J. Beck's inaugural presidential column ("This is Our Time to Shine: Opportunities in a Recession") contained in this issue.-Editor

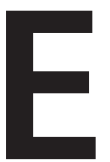

very library that I have worked in over the last twenty-plus years has had at least one staff member grumbling about how often they have to give directions to the restroom. They grumble about patrons who need lessons in reading signs and architects who evilly plan library buildings with invisible restrooms or restrooms far from the entrance. My question is this: Why grumble? This is our chance to shine, to invite people in. While it's true that any trained monkey could point in the correct direction, I would like to believe that human beings aspire to be a bit more helpful than this. In the current economy, with declining numbers of reference transactions and dwindling budgets, every patron encounter is important. These are not just people in need; every one of them has potential. They are potential Nobel Prize winners, potential legislators, potential parents of eager readers, potential library enthusiasts, children with future academic potential, and maybe even future library supporters.

Put yourself on the other side of the desk and rethink why someone might be asking a particular question. In the case of questions such as "where's the restroom?" most likely the person has never been in the building before. Yes, you've answered the question a bazillion times, but most people only ask the question on their first visit. Despite many efforts to the contrary, we are still fighting librarian stereotypes of cantankerous old ladies who shush people. Here is a golden opportunity to make a positive first impression, be welcoming, and influence a new person about the helpfulness of library staff. These interactions, in turn, affect the eagerness of visitors to return in the future.

Patrons frequently ask for directions even when the person they are asking is standing right next to a sign that gives the answer. Clearly, some people prefer to ask a human being rather than take the time to read building signs. Habits of people in a new environment often include asking directional questions first because they are less threatening. If they do okay, and feel comfortable, they work their way up to more 


\section{FROM THE EDITOR}

complicated questions later on. Directional questions may seem mundane, but they can be the first step toward answering future needs and instilling confidence in the person asking the question.

Have you ever noticed that patrons working at computers near public service desks often overhear conversations? If you watch, you will occasionally see a nearby person looking up and smiling after a joke someone made at the desk. They might even raise an eyebrow after being startled by a particular comment. Have you ever wondered if that person sitting near the desk is too shy, or too embarrassed, to ask a question? Could it be they asked a simple question in the past and were affronted by a less than enthusiastic staff member?

Working at a public service desk can definitely get tiring after a while. Repetition can wear down almost anyone, and many libraries have put in an "information desk" to siphon off directional questions to ease the burden on other public service desks. While this may seem to help relieve repetition among a number of desks, the bulk of the repetition goes to a smaller number of individuals who are likely to wear down faster. Very few people can manage cheerful countenances on a constant basis, especially when faced with recurring questions or for a long period of time. Each staff member has a breaking point of a maximum number of hours beyond which they cannot be expected to retain their sanity, let alone be welcoming. If you seem to reach your breaking point too often, maybe it is time to cut back your public contact hours or take a long overdue vacation. Remember, all patrons are important—even ones that are "just" asking directional questions. They are the reason we are here.
I recently read an advice column in Managing People at Work (a newsletter published by McMurry) that recommended pretending each staff member is a volunteer to ensure we show appreciation more often. This can easily be applied to many service desk encounters. Pretend each person is your mother, the next Louis Pasteur, or the library director's spouse. The question is important to them, or they would not have taken the time or effort to ask it.

Library desk staff regularly can, and do, affect visitors' first impressions. Try coming through the front door of your library and pretending you are a first-time visitor. Go visit a nearby library and see what reaction you get when you ask a few simple questions. Which library staff make you feel at home and why? Do any of them annoy you enough to not ask questions in future? Why? Use this information to rethink how patrons may feel as they enter your library and have a question.

I still get a chuckle out of patrons who ask "do you have a restroom?" They don't seem to want to know where it is ... simply whether or not we have one. It has been a long time since a library was built without public restrooms, and every now and then I have to work hard to resist the ornery urge to see their reaction if I say "no." After all, they are in obvious need, and I am there to help them find their way. If you are tired of hearing "where's the restroom?" then maybe it's time to rethink your choice of jobs or how you perform it. Simply put, either stop working at a public help desk or take the challenge to rejuvenate your patron interactions and become a positive face for your library. 